\title{
Rates and methods of phosphorus application in cabbage crop ${ }^{1}$
}

\author{
Luiz Otávio Duarte ${ }^{2}$, Leonardo Angelo de Aquino ${ }^{3}$, \\ Ilídio Augusto Borges Caixeta ${ }^{3}$, Felipe Augusto Reis Gonçalves ${ }^{3}$, Marcelo Rodrigues dos Reis ${ }^{3}$
}

\begin{abstract}
The efficiency of phosphate fertilization may be reduced by incorporating the fertilizer to the soil using a rotary tiller, which is a method commonly adopted to grow vegetables. This study aimed to evaluate the yield of cabbage crop and the efficiency of phosphate fertilization based on rates and application methods of $\mathrm{P}$ to the soil. Four experiments were carried out [two using broadcasting application $\left(0 \mathrm{~kg} \mathrm{ha}^{-1}, 200 \mathrm{~kg} \mathrm{ha}^{-1}\right.$, $400 \mathrm{~kg} \mathrm{ha}^{-1}, 800 \mathrm{~kg} \mathrm{ha}^{-1}$ and $1,600 \mathrm{~kg} \mathrm{ha}^{-1}$ of $\mathrm{P}_{2} \mathrm{O}_{5}$ ) and two using localized application $\left(0 \mathrm{~kg} \mathrm{ha}^{-1}, 80 \mathrm{~kg} \mathrm{ha}^{-1}, 160 \mathrm{~kg} \mathrm{ha}^{-1}\right.$, $320 \mathrm{~kg} \mathrm{ha}^{-1}$ and $640 \mathrm{~kg} \mathrm{ha}^{-1}$ of $\mathrm{P}_{2} \mathrm{O}_{5}$, combined with the presence or absence of phosphating - application of $200 \mathrm{~kg} \mathrm{ha}^{-1}$ of $\mathrm{P}_{2} \mathrm{O}_{5}$ by broadcasting)] in two growing sites [one with low (A) and another with high (B) content of $\mathrm{P}$, both showing a very clayey texture]. The rates of $252 \mathrm{~kg} \mathrm{ha}^{-1}$ and $284 \mathrm{~kg} \mathrm{ha}^{-1}$ of $\mathrm{P}_{2} \mathrm{O}_{5}$ were estimated to obtain the maximum economic productivity in the broadcasting application at the sites $\mathrm{A}$ and $\mathrm{B}$, respectively. The best rates were $183 \mathrm{~kg} \mathrm{ha}^{-1}$ and $146 \mathrm{~kg} \mathrm{ha}^{-1}$ of $\mathrm{P}_{2} \mathrm{O}_{5}$ with the localized application of $\mathrm{P}$ without phosphating at the sites $\mathrm{A}$ and $\mathrm{B}$, respectively. To obain $95 \%$ of maximum yield, the recovery efficiency was $48.9 \%$ and $30.0 \%$ at the sites A and B, respectively. For the localized application of $\mathrm{P}$ in the absence of phosphating, these values were $44.6 \%$ and $60.4 \%$ at the sites $\mathrm{A}$ and $\mathrm{B}$, respectively. With phosphating, the recovery efficiency decreased significantly. The localized application of $\mathrm{P}$ is more efficient than the broadcasting application to supply nutrients and increase the cabbage yield.
\end{abstract}

KEYWORDS: Brassica oleracea var. capitata, localized phosphorous application, phosphate fertilization.

\section{INTRODUCTION}

Even under the application of high rates of phosphate fertilizers, the accumulation levels of $\mathrm{P}$ by plants is low. This is due to the low natural $\mathrm{P}$ content in most Brazilian soils and the high fixation

\section{RESUMO}

\section{Doses e modos de aplicação de}

fósforo em cultivo de repolho

A eficiência da adubação fosfatada pode ser reduzida pela incorporação do fertilizante ao solo com enxada rotativa, método que é comumente adotado no cultivo de hortaliças. Objetivou-se avaliar a produtividade de repolho e a eficiência de adubação fosfatada, em função de doses e modos de aplicação de $\mathrm{P}$ ao solo. Foram conduzidos quatro experimentos [dois com aplicação a lanço $\left(0 \mathrm{~kg} \mathrm{ha}^{-1}, 200 \mathrm{~kg} \mathrm{ha}^{-1}, 400 \mathrm{~kg} \mathrm{ha}^{-1}, 800 \mathrm{~kg} \mathrm{ha}^{-1} \mathrm{e} 1.600 \mathrm{~kg} \mathrm{ha}^{-1}\right.$ de $\left.\mathrm{P}_{2} \mathrm{O}_{5}\right)$ e dois com aplicação localizada $\left(0 \mathrm{~kg} \mathrm{ha}^{-1}, 80 \mathrm{~kg} \mathrm{ha}^{-1}\right.$, $160 \mathrm{~kg} \mathrm{ha}^{-1}, 320 \mathrm{~kg} \mathrm{ha}^{-1}$ e $640 \mathrm{~kg} \mathrm{ha}^{-1}$ de $\mathrm{P}_{2} \mathrm{O}_{5}$, combinados com a presença ou ausência de fosfatagem - aplicação a lanço de $200 \mathrm{~kg} \mathrm{ha}^{-1}$ de $\mathrm{P}_{2} \mathrm{O}_{5}$ )], em dois locais de cultivo [solo de menor (A) e maior (B) disponibilidade de $\mathrm{P}$, ambos de textura muito argilosa]. As doses de $252 \mathrm{~kg} \mathrm{ha}^{-1}$ e $284 \mathrm{~kg} \mathrm{ha}^{-1}$ de $\mathrm{P}_{2} \mathrm{O}_{5}$ foram estimadas para a obtenção da máxima produtividade econômica com a aplicação a lanço nos locais Ae B, respectivamente. As melhores doses foram $183 \mathrm{~kg} \mathrm{ha}^{-1} \mathrm{e}$ $146 \mathrm{~kg} \mathrm{ha}^{-1}$ de $\mathrm{P}_{2} \mathrm{O}_{5}$ com a aplicação localizada de $\mathrm{P}$ sem fosfatagem nos locais A e B, respectivamente. A eficiência de recuperação para a obtenção de $95 \%$ da máxima produtividade foi de 48,9 \% e 30,0 \% nos locais A e B, respectivamente. Para o P aplicado localizado na ausência de fosfatagem, estes índices foram de 44,6 \% e 60,4 \% nos locais A e B, respectivamente. Com a fosfatagem, a eficiência de recuperação diminui de forma significativa. A aplicação localizada de P é mais eficiente que a aplicação a lanço no fornecimento de nutrientes e para a produtividade de repolho.

PALAVRAS-CHAVE: Brassica oleracea var. capitata, aplicação localizada de fósforo, adubação fosfatada.

of Fe and $\mathrm{Al}$ oxyhydroxides, making it unavailable to plants (Novais et al. 2007, Raij 2011). In oleraceous crops, P fixation is enhanced by application methods of phosphate fertilizers, usually in total area and followed by the incorporation up to $15-20 \mathrm{~cm}$. These application methods increase the contact between

1. Received: Jul. 27, 2018. Accepted: Mar. 14, 2019. Published: Jun. 28, 2019. DOI: 10.1590/1983-40632019v4954191.

2. Universidade Estadual Paulista "Júlio de Mesquita Filho", Faculdade de Ciências Agrárias e Veterinárias, Departamento de Produção Vegetal, Jaboticabal, SP, Brasil. E-mail/ORCID: luizotavioduarte@folha.com.br/0000-0003-0187-7456.

3. Universidade Federal de Viçosa, Instituto de Ciências Agrárias, Rio Paranaíba, MG, Brasil.

E-mail/ORCID: aquino.ufv@gmail.com/0000-0002-7764-730X, caixeta.ilidio@gmail.com/0000-0002-2611-495X, felipe.a.agro@gmail.com/0000-0003-3541-0395, reisagro@gmail.com/0000-0003-4825-9815. 
nutrient and soil, hence the fixation (Büll et al. 2004), which decreases the phosphate fertilization efficiency (Sousa et al. 2010).

To increase the efficiency of phosphate fertilization, it is important to reduce the amounts of $P$ applied to the soil (Miyazawa et al. 2011) and production costs, since Brazil imports more than $40 \%$ of the phosphate fertilizers used locally (ANDA 2015). Moreover, the energy needed to produce phosphate fertilizers is high and the raw materials come from non-renewable sources.

Due to the P fixation in tropical soils, its adequate availability is guaranteed by applying high rates or reducing the volume of fertilized soil (Büll et al. 2004). In order to minimize eutrophication and decrease production costs, the volume of fertilized soil is reduced (Sharangi \& Sahu 2009), what is more efficient than reducing the volume in the total area application (phosphating), especially for soluble sources of P (Franzini et al. 2009). The use of soluble sources is justified in shorter-cycle crops because of the rapid availability thereof (Chien et al. 2010). Therefore, studies comparing phosphate fertilization in total and localized areas are common for extensive crops (Resende et al. 2006, Carneiro et al. 2008, Oliveira Júnior et al. 2008, Santos et al. 2008, Franzini et al. 2009, Nunes et al. 2011, Barbosa et al. 2015). However, there are few studies about application methods of $\mathrm{P}$, despite the high rates of phosphate fertilizers applied in vegetable crops (Büll et al. 2004).

Phosphate fertilization increases the cabbage yield, even in P-rich soils (Cecílio Filho et al. 2013). Although the latter authors tested rates up to $720 \mathrm{~kg} \mathrm{ha}^{-1}$ of $\mathrm{P}_{2} \mathrm{O}_{5}$ in soil with $93 \mathrm{mg} \mathrm{dm}^{-3}$ of $\mathrm{P}$ in resin, they obtained $67.5 \mathrm{Mg} \mathrm{ha}^{-1}$ of cabbage at $430 \mathrm{~kg} \mathrm{ha}^{-1}$ of $\mathrm{P}_{2} \mathrm{O}_{5}$. However, Deenik et al. (2006) tested rates between $0 \mathrm{~kg} \mathrm{ha}^{-1}$ and $198 \mathrm{~kg} \mathrm{ha}^{-1}$ of $\mathrm{P}$ in soil with $351 \mathrm{mg} \mathrm{dm}^{-3}$ of $\mathrm{P}$ and verified a positive response with rates up to $50 \mathrm{~kg} \mathrm{ha}^{-1}$ of $\mathrm{P}$. Thus, studies with phosphate fertilization are controversial and there is a lack of information for tropical soils with low content of P. In addition, cabbage is able to mobilize and uptake $\mathrm{P}$ from the soil by additional mechanisms, such as exudation of citric acid (Dechassa \& Schenk 2004), what may be related to the least expressive response to $\mathrm{P}$, if compared to other vegetables.

In official recommendations, the level of $\mathrm{P}$ in the soil is the main criterion to determine the rates of phosphate fertilizer, which differ among the available publications. Such rates range from $50 \mathrm{~kg} \mathrm{ha}^{-1}$ to $400 \mathrm{~kg} \mathrm{ha}^{-1}$ of $\mathrm{P}_{2} \mathrm{O}_{5}$ (Fontes 1999) and from $200 \mathrm{~kg} \mathrm{ha}^{-1}$ to $600 \mathrm{~kg} \mathrm{ha}^{-1}$ of $\mathrm{P}_{2} \mathrm{O}_{5}$ (Trani et al. 1997).

The application method may influence the $\mathrm{P}$ rates for cabbage crops. Thus, this study aimed to evaluate the yield of cabbage crops and the efficiency of phosphate fertilization according to rates and application methods of $P$.

\section{MATERIAL AND METHODS}

Four experiments were carried out, being two with localized application of $\mathrm{P}$ and two with broadcasting application, in soils with low (site A) and high (site B) P levels. They were conducted in Rio Paranaíba, Minas Gerais state, Brazil, at an altitude of $1,100 \mathrm{~m}$, where the predominant climate is Cwa, according to the Köppen-Geiger classification (Peel et al. 2007), which is characterized by a dry season and a well defined rainy period occuring between October and March.

The experiments initiated on 20 December 2014 and 24 January 2015, and the collections took place on 06 March 2015 and 17 April 2015, respectively at the growing sites $\mathrm{A}$ and $\mathrm{B}$. The soil of both sites is classified as a Red Yellow Latosol, with a very clayey texture. The soils with low and high levels of $\mathrm{P}$ presented the following chemical attributes, respectively: $\mathrm{pH}$ (water; ratio $1: 2.5$ ) $=$ 5.2 and 5.3; $\mathrm{P}_{\text {remaining }}=14.8 \mathrm{mg} \mathrm{L}^{-1}$ and $10.7 \mathrm{mg} \mathrm{L}^{-1}$; $\mathrm{P}\left(\right.$ Mehlich-1) $=1.6 \mathrm{mg} \mathrm{dm}^{-3}$ and $4.6 \mathrm{mg} \mathrm{dm}^{-3}$; $\mathrm{K}\left(\right.$ Mehlich-1) $=59 \mathrm{mg} \mathrm{dm}^{-3}$ and $86 \mathrm{mg} \mathrm{dm}^{-3}$; $\mathrm{Ca}^{2+}=2.6 \mathrm{cmol}_{\mathrm{c}} \mathrm{dm}^{-3}$ and $2.4 \mathrm{cmol}_{\mathrm{c}} \mathrm{dm}^{-3} ; \mathrm{Mg}^{2+}=$ $0.6 \mathrm{cmol}_{c} \mathrm{dm}^{-3}$ and $0.5 \mathrm{cmol}_{c} \mathrm{dm}^{-3} ; \mathrm{Al}^{3+}=0.3 \mathrm{cmol} \mathrm{dm}^{-3}$ and $0.3 \mathrm{cmol}_{\mathrm{c}} \mathrm{dm}^{-3} ; \mathrm{H}+\mathrm{Al}=6.8 \mathrm{cmol}_{\mathrm{c}} \mathrm{dm}^{-3}$ and $6.1 \mathrm{cmol}_{\mathrm{c}} \mathrm{dm}^{-3}$; organic matter $=32 \mathrm{~g} \mathrm{~kg}^{-1}$ and $24 \mathrm{~g} \mathrm{~kg}^{-1}$.

The cabbage cultivar used was 'Astrus Plus', an F1 hybrid with compact heads, medium to large size, slightly flattened shape, and mass ranging from $1.4 \mathrm{~kg}$ to $2.2 \mathrm{~kg}$. Most farmers from the Alto Paranaíba region use this cultivar because it can grow all year long. The seedlings were produced in trays with 200 cells, under a protected environment, using an agricultural substrate composed of coconut fiber and vermiculite.

Rates of $0 \mathrm{~kg} \mathrm{ha}^{-1}, 200 \mathrm{~kg} \mathrm{ha}^{-1}, 400 \mathrm{~kg} \mathrm{ha}^{-1}$, $800 \mathrm{~kg} \mathrm{ha}^{-1}$ and $1,600 \mathrm{~kg} \mathrm{ha}^{-1}$ of $\mathrm{P}_{2} \mathrm{O}_{5}$ were tested with $\mathrm{P}$ applied by broadcasting in an experiment designed 
as a randomized block, with four replications. The plots were composed of five rows with $10 \mathrm{~m}$ length, spaced at $0.40 \mathrm{~m}$ between rows and $0.35 \mathrm{~m}$ between plants, totaling $20 \mathrm{~m}^{2}$. The three central rows, except $1.5 \mathrm{~m}$ from the edges, were the useful plots.

Rates of $0 \mathrm{~kg} \mathrm{ha}^{-1}, 80 \mathrm{~kg} \mathrm{ha}^{-1}, 160 \mathrm{~kg} \mathrm{ha}^{-1}$, $320 \mathrm{~kg} \mathrm{ha}^{-1}$ and $640 \mathrm{~kg} \mathrm{ha}^{-1}$ of $\mathrm{P}_{2} \mathrm{O}_{5}$ were tested with localized application of $\mathrm{P}$ in the presence or absence of phosphate $\left(200 \mathrm{~kg} \mathrm{ha}^{-1}\right.$ of $\mathrm{P}_{2} \mathrm{O}_{5}$ by broadcasting application). This experiment was designed as a randomized block, in a split-plot scheme, in which phosphate was assigned to the plots and rates of $\mathrm{P}$ to the subplots, with four replications. The subplots were composed of five rows with $10 \mathrm{~m}$ length, spaced at $40 \mathrm{~cm}$ between rows and $35 \mathrm{~cm}$ between plants, totaling $20 \mathrm{~m}^{2}$. The three central rows, except $1.5 \mathrm{~m}$ from the edges, were the useful plots.

At the growing site A (low P level), the application consisted of $1.5 \mathrm{Mg} \mathrm{ha}^{-1}$ of limestone ( $85 \%$ of PRNT, $37 \%$ of $\mathrm{CaO}$ and $14 \%$ of $\mathrm{MgO}$ ) and, at the site $\mathrm{B}$ (high P level), $0.7 \mathrm{Mg} \mathrm{ha}^{-1}$ of gypsum and $1.6 \mathrm{Mg} \mathrm{ha}^{-1}$ of limestone (80\% of PRNT, $42 \%$ of $\mathrm{CaO}$ and $10.9 \%$ of $\mathrm{MgO}$ ). The soil preparation consisted of one subsoiling, two harrowings and one rotary tiller with hole marking. Regarding the broadcasting method, the phosphate fertilizer was incorporated into the soil with a rotary tiller at a depth of $0.15 \mathrm{~m}$. In the experiment with localized application of $\mathrm{P}$, after the rotary tiller operation, furrows were opened at a depth of $0.10 \mathrm{~m}$, where the phosphate fertilizer was placed. The furrows were closed and the holes were spaced at $0.35 \mathrm{~m}$ from each other. The total nitrogen and potassium fertilizers contained $270 \mathrm{~kg} \mathrm{ha}^{-1}$ and $300 \mathrm{~kg} \mathrm{ha}^{-1}$ of $\mathrm{N}$ and $\mathrm{K}_{2} \mathrm{O}$, respectively (Aquino et al. 2009).

The seedlings were transplanted at 35 days after sowing. At the transplant occasion, $30 \mathrm{~kg} \mathrm{ha}^{-1}$ of $\mathrm{N}$ (via ammonium nitrate), $60 \mathrm{~kg} \mathrm{ha}^{-1}$ of $\mathrm{K}_{2} \mathrm{O}$ (via potassium chloride), $1.5 \mathrm{~kg} \mathrm{ha}^{-1}$ of $\mathrm{B}$ (via boric acid) and $5 \mathrm{~kg} \mathrm{ha}^{-1}$ of $\mathrm{Zn}$ (via zinc sulphate) were applied by broadcasting and incorporated using a rotary tiller. The $\mathrm{P}$ source used in both experiments was simple superphosphate $\left(20 \%\right.$ of $\left.\mathrm{P}_{2} \mathrm{O}_{5}\right)$. Three topdressing fertilizations were performed at 10, 25 and 40 days after transplanting the seedlings. In each application, $80 \mathrm{~kg} \mathrm{ha}^{-1}$ of $\mathrm{N}$ and $80 \mathrm{~kg} \mathrm{ha}^{-1}$ of $\mathrm{K}_{2} \mathrm{O}$ were applied as 20-00-20.

In pre-planting, oxyfluorfen was applied to control weeds. Inhibitors of ACCase were applied in post-planting to control Poaceae, and the other weeds were manually controlled. Pest management was carried out with products recommended for the crop, when in presence of pests. When necessary, irrigations were performed by conventional spraying, according to the data collected in meteorological stations installed close to the experiments.

At the beginning of the head-forming stage, the content of $\mathrm{P}\left(\mathrm{g} \mathrm{kg}^{-1}\right)$ in younger expanded leaves was determined to characterize the nutritional status of $\mathrm{P}$. Ten leaves were collected, washed and dried in an oven with forced air ventilation at $70^{\circ} \mathrm{C}$, for $72 \mathrm{~h}$. After that, the samples were ground in a Wiley mill equipped with a $1.27 \mathrm{~mm}$ sieve and submitted to $P$ analysis (Malavolta et al. 1997).

The plants were harvested when they showed a well-shaped head and the firmness demanded by consumers. The following variables were evaluated: 1) yield $\left(\mathrm{Mg} \mathrm{ha}^{-1}\right)$ : obtained by the fresh weight of cabbage heads; 2) agronomic efficiency (AE): ratio between yield and applied dose of $\mathrm{P}_{2} \mathrm{O}_{5}$, calculated by the following equation: $\mathrm{AE}=$ Y fer - Ynfer/Nap, in which $A E$ is the agronomic efficiency $\left(\mathrm{kg} \mathrm{kg}^{-1}\right)$, Yfer the yield in the fertilized plot $\left(\mathrm{kg} \mathrm{ha}^{-1}\right)$, Ynfer the yield in the non-fertilized plot $\left(\mathrm{kg} \mathrm{ha}^{-1}\right)$ and $N A p$ the amount of nutrient applied to the soil $\left(\mathrm{kg} \mathrm{ha}^{-1}\right)$; $3)$ recovery efficiency $(\mathrm{RE})$ : measures the percentage of P recovered from the fertilizer applied to the plants, which is calculated with the following equation (Fageria 2009): RE $=($ Nfer - Nnfer $) / N A p \times 100$, in which $R E$ is the recovery efficiency of $\mathrm{P}$ applied via fertilizer (\%), Nfer the amount of nutrient absorbed by plants in the fertilized plot $\left(\mathrm{kg} \mathrm{ha}^{-1}\right)$, Nnfer the amount of nutrient absorbed by plants in the non-fertilized plot $\left(\mathrm{kg} \mathrm{ha}^{-1}\right)$ and $N A p$ the amount of nutrient applied to the soil $\left.\left(\mathrm{kg} \mathrm{ha}^{-1}\right) ; 4\right)$ extraction and export of $\mathrm{P}\left(\mathrm{kg} \mathrm{ha}^{-1}\right)$ : the $\mathrm{P}$ exported was the $\mathrm{P}$ accumulated in the cabbage head, which was obtained by the product between the dry matter and the P content of the head. The accumulation of $\mathrm{P}$ in the external leaves was calculated using the product between the dry matter and the $\mathrm{P}$ content. The $\mathrm{P}$ extracted from the plant shoot was obtained by summing the $\mathrm{P}$ accumulated in the external leaves and in the head; 5) P-levels in the soil $\left(\mathrm{mg} \mathrm{dm}^{-3}\right)$ : in each plot, 15 soil samples were collected in the rows and 15 between the rows, at a depth of $15 \mathrm{~cm}$, to determine the $\mathrm{P}$ content, using the extractors Mehlich-1 (Tedesco et al. 1995) and Mehlich-3 (Mehlich 1984).

Data from the experiments with $\mathrm{P}$ applied by broadcasting were submitted to analysis of variance 
and regression. The best rates (maximum economic efficiency) were defined as those that allowed to reach $95 \%$ of the maximum yield estimated by the fitted models. The experiment with localized application of $\mathrm{P}$, combined or not with phosphating, had the degrees of freedom of factors unfolded, and a regression analysis was performed for rates of $\mathrm{P}$ and phosphating within each dose applied at the furrow, if compared by the $\mathrm{F}$ test. When necessary, the data were transformed to meet the analysis of variance presuppositions.

\section{RESULTS AND DISCUSSION}

Rates of $252 \mathrm{~kg} \mathrm{ha}^{-1}$ and $284 \mathrm{~kg} \mathrm{ha}^{-1}$ of $\mathrm{P}_{2} \mathrm{O}_{5}$ were estimated to obtain the maximum economic productivity in the broadcasting application. They corresponded to $119.7 \mathrm{Mg} \mathrm{ha}^{-1}$ and $127.2 \mathrm{Mg} \mathrm{ha}^{-1}$, respectively at the sites $\mathrm{A}$ and $\mathrm{B}$ (Figure 1a). The best rates were $183 \mathrm{~kg} \mathrm{ha}^{-1}$ and $146 \mathrm{~kg} \mathrm{ha}^{-1}$ of $\mathrm{P}_{2} \mathrm{O}_{5}$, with localized application of $\mathrm{P}$ without phosphating, which allowed a yield of $108.4 \mathrm{Mg} \mathrm{ha}^{-1}$ and $120.6 \mathrm{Mg} \mathrm{ha}^{-1}$, respectively at the sites $\mathrm{A}$ and $\mathrm{B}$ (Figure $1 \mathrm{~b}$ ). The site $\mathrm{B}$ showed a higher yield than the site $\mathrm{A}$, regardless of the application method of P. Higher levels of $\mathrm{P}$ at the site $\mathrm{B}$ and cultivation in the winter period, which is more favorable to the crop, may explain the higher yields, regarding the site A. Lower rates were used in the localized application, although with similar yields, what may be attributed to the partial saturation of adsorption sites of $\mathrm{P}$, and provided an increase in the $\mathrm{P}$ levels in the soil close to the plant roots.
Phosphating provided a more significant increase in the head yield at the site A with low P content in the soil (Table 1), what may be related to the root system growth. The P present in the region may not have been able to supply all the plants needs. Therefore, the roots were looking for P externally to this region (Novais \& Smith 1999), what was guaranteed by phosphating, given the low content of $\mathrm{P}$ in the soil at the site $\mathrm{A}$.

The average yield at the site A was $115.4 \mathrm{Mg}$ $\mathrm{ha}^{-1}$, while, at the site $\mathrm{B}$, it was $132.1 \mathrm{Mg} \mathrm{ha}^{-1}$ (Table 1). Thus, such yields are above $56.5 \mathrm{Mg} \mathrm{ha}^{-1}$, which was the amount found by Moreira et al. (2011), and $44.5 \mathrm{Mg} \mathrm{ha}^{-1}$ and $30.0 \mathrm{Mg} \mathrm{ha}^{-1}$, verified by Correa et al. (2013), what may be related to the use of different cultivars from the one used in the present study. However, Cecílio Filho et al. (2011), using the 'Astrus Plus' cultivar, obtained $72.7 \mathrm{Mg} \mathrm{ha}^{-1}$ for cabbage, what may be attributed to the lower plant population. The possible explanation for this result is the ability of cabbage to mobilize and absorb $\mathrm{P}$ in the soil by additional mechanisms, such as organic citrate acid exudation (Dechassa \& Schenk 2004).

The agronomic efficiency reduced with increasing rates in both application methods (Figures 1c and 1d). In addition, the values obtained were higher for the site A than for the site B, what may be attributed to the lower $\mathrm{P}$ content at the first growing site. For $\mathrm{P}$ applied by broadcasting, the agronomic efficiency to obtain $95 \%$ of maximum yield was $493 \mathrm{~kg} \mathrm{~kg}^{-1}$ at the site A and $345 \mathrm{~kg} \mathrm{~kg}^{-1}$ at the site B (Figure 1c). For P

Table 1. Yield, agronomic efficiency (AE), recovery efficiency (RE), P content in the leaf, extraction and export of P for P localized in the absence and presence of phosphating.

\begin{tabular}{|c|c|c|c|c|c|c|c|c|c|c|c|}
\hline \multirow{3}{*}{ Variable } & \multirow{3}{*}{ Phosphating } & \multicolumn{10}{|c|}{ Rate $\left(\mathrm{kg} \mathrm{ha}^{-1}\right.$ of $\left.\mathrm{P}_{2} \mathrm{O}_{5}\right)$} \\
\hline & & 0 & 80 & 160 & 320 & 640 & 0 & 80 & 160 & 320 & 640 \\
\hline & & \multicolumn{5}{|c|}{ Site A } & \multicolumn{5}{|c|}{ Site B } \\
\hline \multirow{2}{*}{$\begin{array}{l}\text { Yield } \\
\left(\mathrm{Mg} \mathrm{ha}^{-1}\right)\end{array}$} & Without & $0.0 \mathrm{~b}^{*}$ & $84.5 \mathrm{~b}$ & $104.1 \mathrm{~b}$ & $111.8 \mathrm{a}$ & $116.5 \mathrm{a}$ & $34.5 \mathrm{~b}$ & $105.8 \mathrm{~b}$ & $121.8 \mathrm{a}$ & $125.1 \mathrm{~b}$ & $128.5 \mathrm{a}$ \\
\hline & With & $119.6 \mathrm{a}$ & $113.7 \mathrm{a}$ & $114.0 \mathrm{a}$ & $117.2 \mathrm{a}$ & $117.7 \mathrm{a}$ & $119.3 \mathrm{a}$ & $129.1 \mathrm{a}$ & $127.5 \mathrm{a}$ & $139.2 \mathrm{a}$ & $132.5 \mathrm{a}$ \\
\hline \multirow{2}{*}{$\begin{array}{l}\mathrm{AE} \\
\left(\mathrm{kg} \mathrm{kg}^{-1}\right)\end{array}$} & Without & - & $1,056.2 \mathrm{a}$ & $650.8 \mathrm{a}$ & $349.5 \mathrm{a}$ & $182.0 \mathrm{a}$ & - & $890.7 \mathrm{a}$ & $545.4 \mathrm{a}$ & $283.1 \mathrm{a}$ & $146.9 \mathrm{a}$ \\
\hline & With & - & $406.1 \mathrm{~b}$ & $316.7 \mathrm{~b}$ & $225.4 \mathrm{~b}$ & $140.2 \mathrm{~b}$ & - & $337.6 \mathrm{~b}$ & $258.3 \mathrm{~b}$ & $201.3 \mathrm{~b}$ & $116.6 \mathrm{~b}$ \\
\hline \multirow{2}{*}{$\begin{array}{l}\mathrm{RE} \\
(\%)\end{array}$} & Without & - & $52.3 \mathrm{a}$ & $54.5 \mathrm{a}$ & $32.3 \mathrm{a}$ & $21.3 \mathrm{a}$ & - & $72.8 \mathrm{a}$ & $61.2 \mathrm{a}$ & $40.9 \mathrm{a}$ & $22.5 \mathrm{a}$ \\
\hline & With & - & $38.3 \mathrm{~b}$ & $32.3 \mathrm{~b}$ & $25.1 \mathrm{~b}$ & $16.7 \mathrm{a}$ & - & $39.2 \mathrm{~b}$ & $31.4 \mathrm{~b}$ & $25.3 \mathrm{~b}$ & $20.8 \mathrm{a}$ \\
\hline \multirow{2}{*}{$\begin{array}{l}\text { P content in the } \\
\text { leaf }\left(\mathrm{g} \mathrm{kg}^{-1}\right)\end{array}$} & Without & $1.9 \mathrm{~b}$ & $2.9 \mathrm{~b}$ & $4.9 \mathrm{~b}$ & $5.9 \mathrm{a}$ & $6.4 \mathrm{a}$ & $4.4 \mathrm{a}$ & $6.0 \mathrm{a}$ & $6.9 \mathrm{a}$ & $7.2 \mathrm{a}$ & $7.4 \mathrm{a}$ \\
\hline & With & $4.3 \mathrm{a}$ & $5.1 \mathrm{a}$ & $5.8 \mathrm{a}$ & $6.4 \mathrm{a}$ & $6.6 \mathrm{a}$ & $6.7 \mathrm{a}$ & $7.3 \mathrm{a}$ & $7.1 \mathrm{a}$ & $7.7 \mathrm{a}$ & $8.2 \mathrm{a}$ \\
\hline \multirow{2}{*}{$\begin{array}{l}\text { Extraction of P } \\
\left(\mathrm{kg} \mathrm{ha}^{-1}\right)\end{array}$} & Without & $1.5 \mathrm{~b}$ & $19.7 \mathrm{~b}$ & $39.5 \mathrm{~b}$ & $46.6 \mathrm{~b}$ & $60.8 \mathrm{a}$ & $17.2 \mathrm{~b}$ & $42.8 \mathrm{~b}$ & $60.1 \mathrm{a}$ & $74.5 \mathrm{a}$ & $80.1 \mathrm{~b}$ \\
\hline & With & $49.2 \mathrm{a}$ & $48.2 \mathrm{a}$ & $52.3 \mathrm{a}$ & $58.5 \mathrm{a}$ & $62.8 \mathrm{a}$ & $49.2 \mathrm{a}$ & $65.3 \mathrm{a}$ & $66.6 \mathrm{a}$ & $74.7 \mathrm{a}$ & $93.6 \mathrm{a}$ \\
\hline \multirow{2}{*}{$\begin{array}{l}\text { Export of P } \\
\left(\mathrm{kg} \mathrm{ha}^{-1}\right)\end{array}$} & Without & $0.0 \mathrm{~b}$ & $17.3 \mathrm{~b}$ & $34.0 \mathrm{~b}$ & $40.3 \mathrm{~b}$ & $49.9 \mathrm{a}$ & $14.6 \mathrm{~b}$ & $37.5 \mathrm{~b}$ & $52.0 \mathrm{a}$ & $64.7 \mathrm{a}$ & $68.4 \mathrm{~b}$ \\
\hline & With & $43.7 \mathrm{a}$ & $42.7 \mathrm{a}$ & $45.3 \mathrm{a}$ & $49.5 \mathrm{a}$ & $53.3 \mathrm{a}$ & $43.5 \mathrm{a}$ & $56.0 \mathrm{a}$ & $57.2 \mathrm{a}$ & $65.0 \mathrm{a}$ & $78.5 \mathrm{a}$ \\
\hline
\end{tabular}



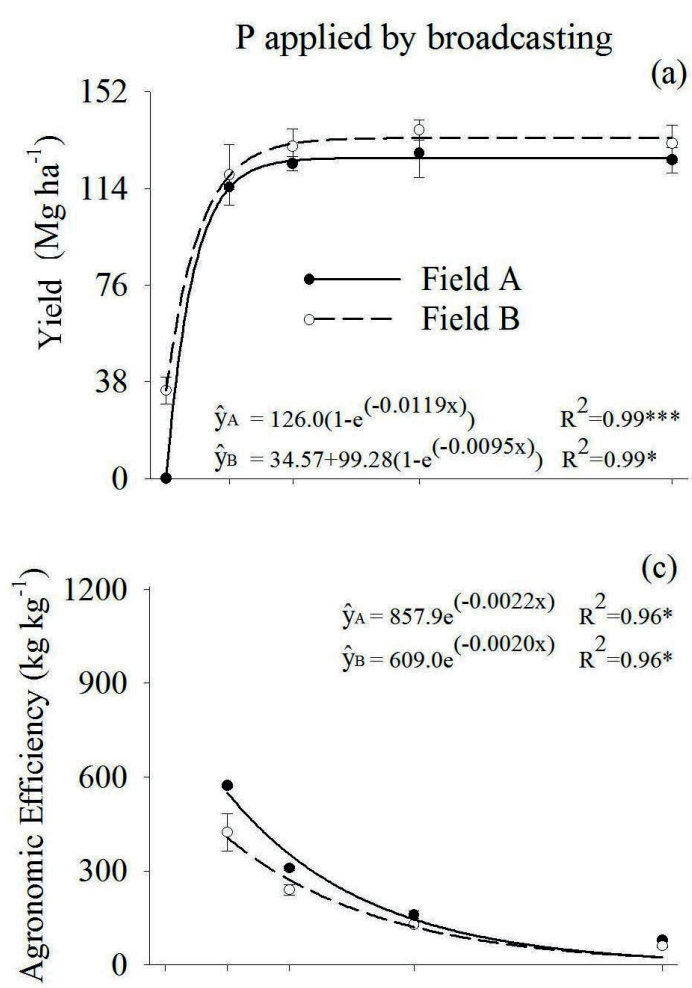

(e)

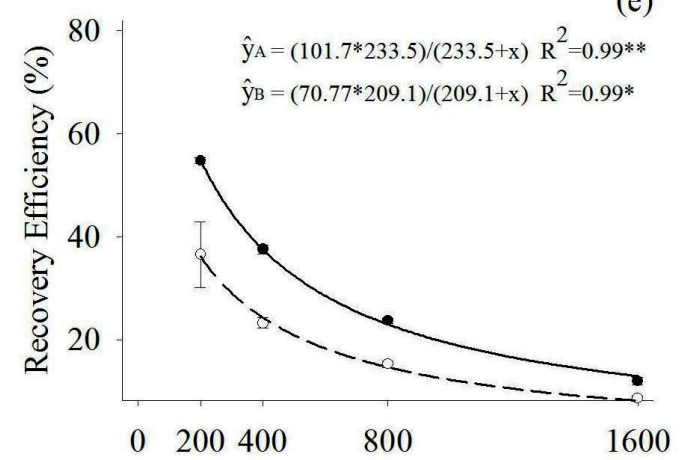

$\mathrm{P}$ applied in row without phosphating

(b)

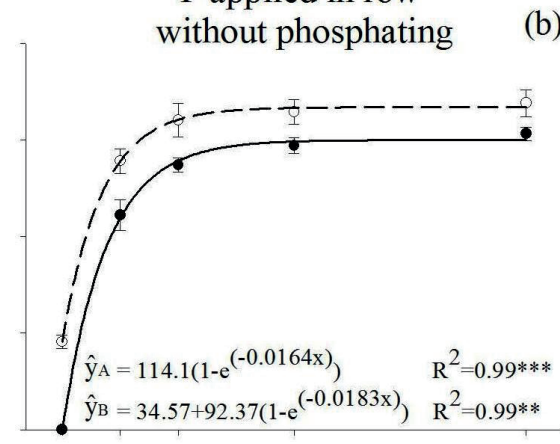

(d)

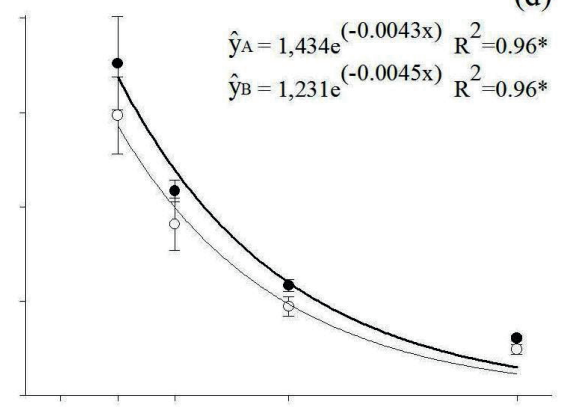

(f)

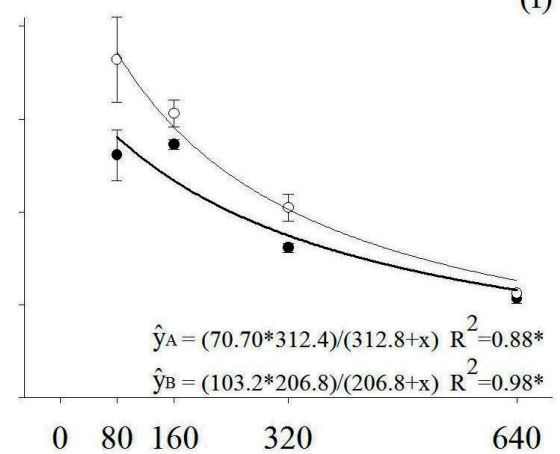

640

Dose $\left(\mathrm{kg} \mathrm{ha}{ }^{-1}\right.$ of $\left.\mathrm{P}_{2} \mathrm{O}_{5}\right)$

Figure 1. Yield of cabbage heads, agronomic efficiency and recovery efficiency of $\mathrm{P}$ in response to rates and methods of $\mathrm{P}$ application in soil with low (site A) and high (site B) levels of P. ***, ** and *: significant at $0.1 \%, 1 \%$ and $5 \%$, respectively, by the t-test.

applied in rows without phosphating, $654 \mathrm{~kg} \mathrm{~kg}^{-1}$ at the site $\mathrm{A}$ and $637 \mathrm{~kg} \mathrm{~kg}^{-1}$ at the site B were found for the best rates (Figure 1d). Phosphating reduced the agronomic efficiency in the localized application of $\mathrm{P}$, especially at the site $\mathrm{B}$ (Table 1). A higher agronomic efficiency with localized application of $\mathrm{P}$ along a maximum yield and similar to the broadcasting application demonstrates a greater efficiency for localized application, if compared to the broadcasting application.
The recovery efficiency reduced with increasing rates of $\mathrm{P}_{2} \mathrm{O}_{5}$ (Figures 1e and 1f) and, to obtain $95 \%$ of maximum yield, the values were $48.9 \%$ and $30.0 \%$, respectively at the sites $\mathrm{A}$ and $\mathrm{B}$ (Figure 1e). For the localized application of $\mathrm{P}$ in the absence of phosphating, the recovery efficiencies were $44.6 \%$ and $60.4 \%$ at the sites A and $\mathrm{B}$, respectively (Figure 1f). With phosphating, the recovery efficiency decreased significantly and ranged from $38.3 \%$ to $16.7 \%$ at the site $\mathrm{A}$, and from 
$39.2 \%$ to $20.8 \%$ at the site B (Table 1 ). Recovery efficiency is the percentage of nutrient applied that the plant absorbed and, therefore, the efficiency of the fertilizer application method.

The content of $\mathrm{P}$ in the diagnostic leaf analysis increased with the rates of $\mathrm{P}$ in the soil (Figures $2 \mathrm{a}$ and $2 \mathrm{~b}$ ). For the broadcasting application, the contents of $\mathrm{P}$ were $4.7 \mathrm{~g} \mathrm{~kg}^{-1}$ and $6.9 \mathrm{~g} \mathrm{~kg}^{-1}$ at the sites $\mathrm{A}$ and $\mathrm{B}$, respectively, to obtain $95 \%$ of maximum yield (Figure 2a). For the localized application of $\mathrm{P}$ without phosphating, the content of $\mathrm{P}$ at the site A was $4.0 \mathrm{~g} \mathrm{~kg}^{-1}$ and, at the site $\mathrm{B}$, it was $6.8 \mathrm{~g} \mathrm{~kg}^{-1}$ (Figure 2b). Phosphating increased the $\mathrm{P}$ content in the leaf only at the site A. Thus, for the localized application of $\mathrm{P}$ with phosphating, the contents ranged from $5.1 \mathrm{~g} \mathrm{~kg}^{-1}$ to $6.6 \mathrm{~g} \mathrm{~kg}^{-1}$ of $\mathrm{P}$ at the site $\mathrm{A}$, and from $7.3 \mathrm{~g} \mathrm{~kg}^{-1}$ to $8.2 \mathrm{~g} \mathrm{~kg}^{-1}$ at the site $\mathrm{B}$ (Table 1). The contents of $\mathrm{P}$ in the leaf observed in this study are higher than those found by Cecílio Filho et al. (2013), who observed $4.3 \mathrm{~g} \mathrm{~kg}^{-1}$ of $\mathrm{P}$ in
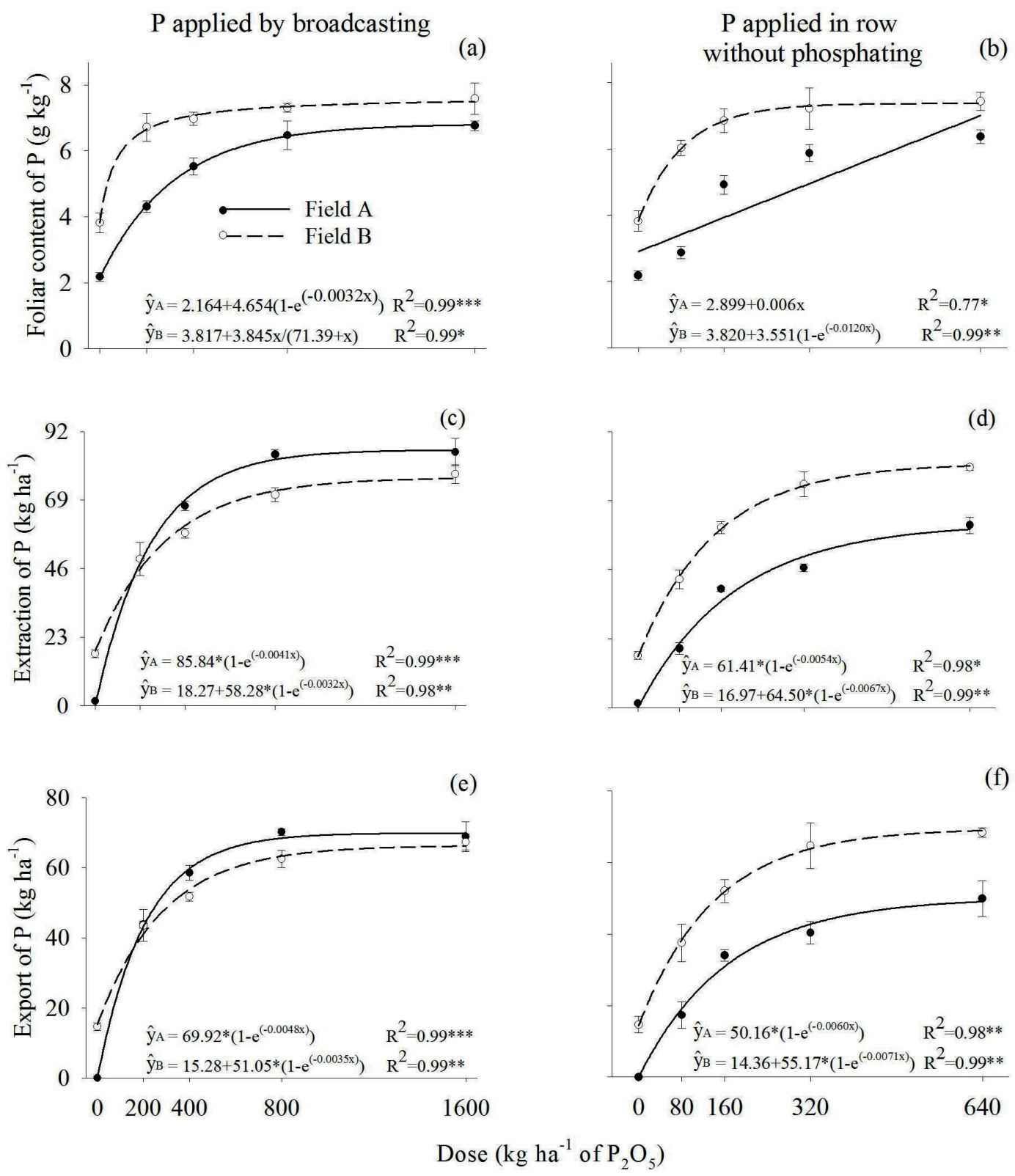

Figure 2. Content of $\mathrm{P}$ in the diagnostic leaf analysis, extraction and export, in response to rates and application methods of $\mathrm{P}$. ***, ** and *: significant at $0.1 \%, 1 \%$ and $5 \%$, respectively, by the t test. A: soil with low content of P; B: soil with high content of $\mathrm{P}$. 
the 'Fuyutoyo' hybrid, applying $720 \mathrm{~kg} \mathrm{ha}^{-1}$ of $\mathrm{P}_{2} \mathrm{O}_{5}$ in the soil with $\mathrm{P}_{\text {resin }}$ of $93.0 \mathrm{mg} \mathrm{dm}^{-3}$. In addition, such contents are above $3.0 \mathrm{~g} \mathrm{~kg}^{-1}$ of $\mathrm{P}$, considered adequate by Malavolta et al. (1997), but within the range of 4.0-7.0 $\mathrm{g} \mathrm{kg}^{-1}$ recommended by Trani \& Raij ( 1997).

The extraction and export of P were contrasting between the growing sites and application methods, with higher values at the site A for the broadcasting application of $\mathrm{P}$ and at the site $\mathrm{B}$ for the localized application of $\mathrm{P}$. Regarding the broadcasting application of $\mathrm{P}$ at $95 \%$ of maximum yield, extractions were $55 \mathrm{~kg} \mathrm{ha}^{-1}$ and $53 \mathrm{~kg} \mathrm{ha}^{-1}$ at the sites A and B, respectively (Figure 2c). Concerning the localized application of $\mathrm{P}$ without phosphating, extractions were $39 \mathrm{~kg} \mathrm{ha}^{-1}$ and $57 \mathrm{~kg} \mathrm{ha}^{-1}$ at the sites A and B, respectively (Figure 2d). These results evinced a wide range of "luxury consumption", because the extraction at the best dose is well below those found at the maximum yield rates for both application methods. For the localized application of $\mathrm{P}$ with phosphating, there was an increase in extractions and exports of $\mathrm{P}$ at both growing sites (Table 1). The $\mathrm{P}$ export exceeded $80 \%$ of what was extracted (Figures $2 \mathrm{e}$ and $2 \mathrm{f}$ ), what highlights the importance of $\mathrm{P}$ replacement. Therefore, soil impoverishment does not occur with harvests.

The values for extraction of $\mathrm{P}$ in the present study differ from those found by Cecílio Filho et al. (2013), who, in a soil with a high content of $P$ and fertilized with $360 \mathrm{~kg} \mathrm{ha}^{-1}$ of $\mathrm{P}_{2} \mathrm{O}_{5}$, obtained an extraction of $24 \mathrm{~kg} \mathrm{ha}^{-1}$ of $\mathrm{P}$ and a yield of $90.4 \mathrm{Mg} \mathrm{ha}^{-1}$. Correa et al. (2013), in a soil with a low content of $\mathrm{P}$ and fertilized with $420 \mathrm{~kg} \mathrm{ha}^{-1}$ of $\mathrm{P}_{2} \mathrm{O}_{5}$, found a similar extraction value $\left(22 \mathrm{~kg} \mathrm{ha}^{-1}\right.$ of $\mathrm{P}$ ), even with a low yield (44.5 $\left.\mathrm{Mg} \mathrm{ha}^{-1}\right)$. Most likely, the high productive potential of the cultivar used in association with the largest plant population was a preponderant factor to obtain the higher yield and, consequently, the higher extraction of $\mathrm{P}$ in the present study.

The content of $\mathrm{P}$ in the soil with broadcasting application was higher between rows than in rows for both the extractors used (Figures $3 \mathrm{a}$ and $3 \mathrm{c}$ ), what shows that the $\mathrm{P}$ absorbed by plants was that close to the roots, since it is a diffusion-transported nutrient (Costa et al. 2006). For the localized application, the contents of $\mathrm{P}$ increased considerably in the cultivation rows in response to the rates (Figures $3 \mathrm{~b}$ and $3 \mathrm{~d}$ ), while, between the rows, there was a slight increase, except at the site B, for the Mehlich-1 extractor (Figure 3b). In general, it was observed that the maximum contents reached in the cultivation rows were close between the application methods, although the maximum dose by broadcasting application was much higher than the one used in the localized application method. Except for the inter-planting lines of the site A, phosphating increased significantly the contents of $\mathrm{P}$ in the soil (Table 2).

Thus, it can be inferred that the P present in the crop row influenced most the yield, being more efficiently provided by the localized application method. Similar results have been observed in other crops under conditions of low content of $\mathrm{P}$ in the soil, especially in soils with oxidic clays. In soybean crops, Barbosa et al. (2015) obtained a maximum yield with the localized application of P. In carrot crops, Gonçalves (2018) verified that, although the yield was higher in the broadcasting application,

Table 2. Content of $\mathrm{P}$ in the soil at the harvest time, in rows and between rows, by Mehlich-1 (M1) and Mehlich-3 (M3) extractors, for localized application of $\mathrm{P}$ in the absence and presence of phosphating.

\begin{tabular}{|c|c|c|c|c|c|c|c|c|c|c|c|c|}
\hline \multirow{3}{*}{ Extractor } & \multirow{3}{*}{$\begin{array}{c}\text { Row/ } \\
\text { Between } \\
\text { rows } \\
\end{array}$} & \multirow{3}{*}{ Phosphating } & \multicolumn{10}{|c|}{ Rate $\left(\mathrm{kg} \mathrm{ha}^{-1}\right.$ of $\left.\mathrm{P}_{2} \mathrm{O}_{5}\right)$} \\
\hline & & & 0 & 80 & 160 & 320 & 640 & 0 & 80 & 160 & 320 & 640 \\
\hline & & & & & Site A & & & & & Site B & & \\
\hline \multirow{4}{*}{ M1 } & \multirow{2}{*}{ Row } & Without & $1.4 \mathrm{a}^{*}$ & $0.7 \mathrm{~b}$ & $1.4 \mathrm{~b}$ & $1.9 \mathrm{~b}$ & $19.9 \mathrm{a}$ & $3.9 \mathrm{~b}$ & $3.8 \mathrm{~b}$ & $5.2 \mathrm{~b}$ & $6.8 \mathrm{~b}$ & $19.2 \mathrm{~b}$ \\
\hline & & With & $0.9 \mathrm{~b}$ & $2.9 \mathrm{a}$ & $2.9 \mathrm{a}$ & $9.6 \mathrm{a}$ & $11.4 \mathrm{~b}$ & $4.5 \mathrm{a}$ & $5.4 \mathrm{a}$ & $6.6 \mathrm{a}$ & $11.6 \mathrm{a}$ & $32.2 \mathrm{a}$ \\
\hline & \multirow{2}{*}{$\begin{array}{l}\text { Between } \\
\text { rows }\end{array}$} & Without & $1.8 \mathrm{a}$ & $0.9 \mathrm{~b}$ & $1.6 \mathrm{a}$ & $1.2 \mathrm{a}$ & $5.3 \mathrm{~b}$ & $3.7 \mathrm{~b}$ & $4.4 \mathrm{a}$ & $4.0 \mathrm{~b}$ & $3.6 \mathrm{~b}$ & $5.4 \mathrm{~b}$ \\
\hline & & With & $0.8 \mathrm{~b}$ & $1.9 \mathrm{a}$ & $1.7 \mathrm{a}$ & $1.3 \mathrm{a}$ & $5.9 \mathrm{a}$ & $4.6 \mathrm{a}$ & $4.7 \mathrm{a}$ & $5.6 \mathrm{a}$ & $4.8 \mathrm{a}$ & $6.0 \mathrm{a}$ \\
\hline \multirow{4}{*}{ M3 } & \multirow{2}{*}{ Row } & Without & $3.9 \mathrm{~b}$ & $2.9 \mathrm{~b}$ & $3.8 \mathrm{~b}$ & $3.9 \mathrm{~b}$ & $14.6 \mathrm{a}$ & $3.9 \mathrm{~b}$ & $4.4 \mathrm{a}$ & $6.0 \mathrm{a}$ & $8.1 \mathrm{a}$ & $19.6 \mathrm{a}$ \\
\hline & & With & $4.5 \mathrm{a}$ & $4.8 \mathrm{a}$ & $6.5 \mathrm{a}$ & $9.4 \mathrm{a}$ & $13.1 \mathrm{a}$ & $4.5 \mathrm{a}$ & $3.8 \mathrm{~b}$ & $4.1 \mathrm{~b}$ & $6.3 \mathrm{~b}$ & $12.8 \mathrm{~b}$ \\
\hline & \multirow{2}{*}{$\begin{array}{l}\text { Between } \\
\text { rows }\end{array}$} & Without & $3.2 \mathrm{~b}$ & $4.8 \mathrm{~b}$ & $5.8 \mathrm{a}$ & $5.7 \mathrm{a}$ & $8.4 \mathrm{~b}$ & $2.9 \mathrm{~b}$ & $3.9 \mathrm{~b}$ & $7.3 \mathrm{a}$ & $10.6 \mathrm{a}$ & $23.4 \mathrm{a}$ \\
\hline & & With & $4.1 \mathrm{a}$ & $5.5 \mathrm{a}$ & $5.3 \mathrm{~b}$ & $5.4 \mathrm{a}$ & $9.3 \mathrm{a}$ & $4.1 \mathrm{a}$ & $4.5 \mathrm{a}$ & $5.5 \mathrm{~b}$ & $4.2 \mathrm{~b}$ & $5.7 \mathrm{~b}$ \\
\hline
\end{tabular}

* Means followed by same letter in the column do not differ statistically by the $\mathrm{F}$ test at $5 \%$ of significance. 
$\mathrm{P}$ applied by broadcasting
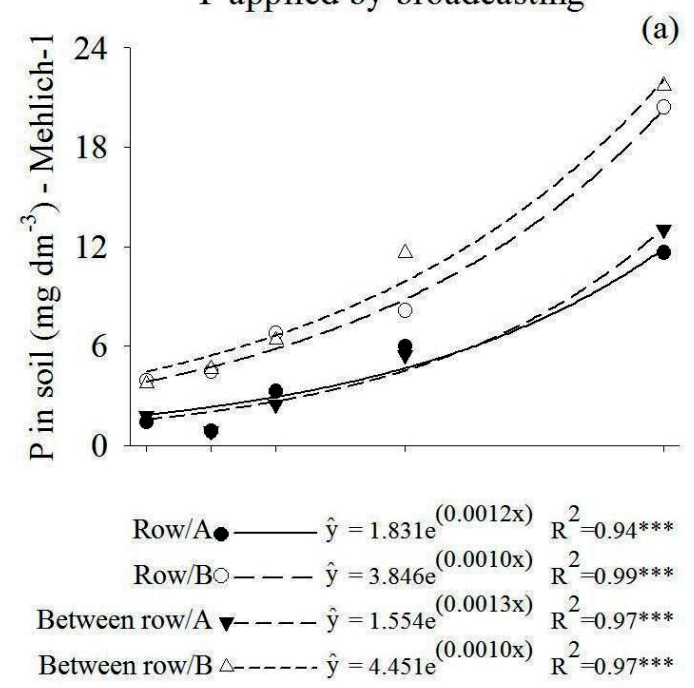

$\mathrm{P}$ applied in row without phosphating

(b)
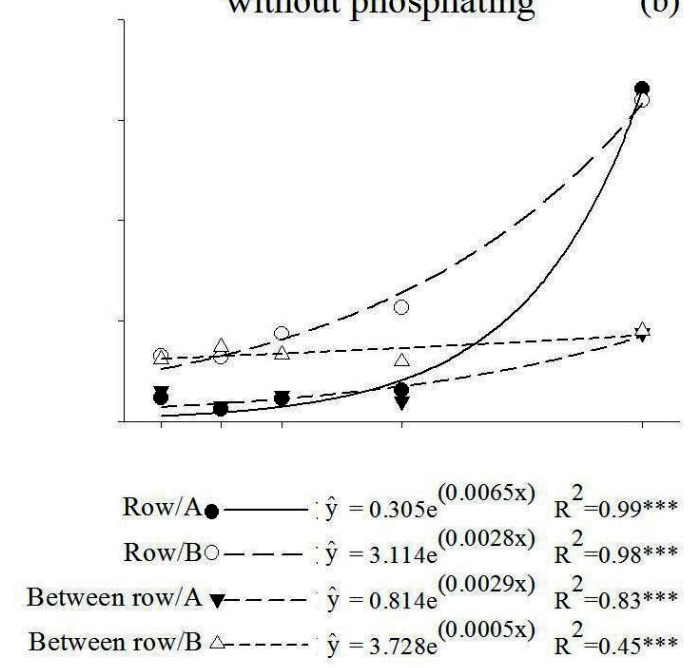

(c)

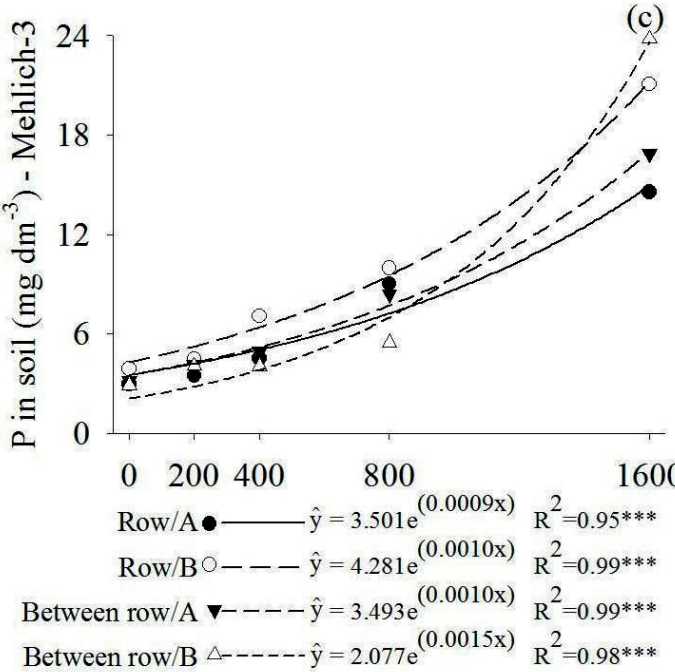

(d)

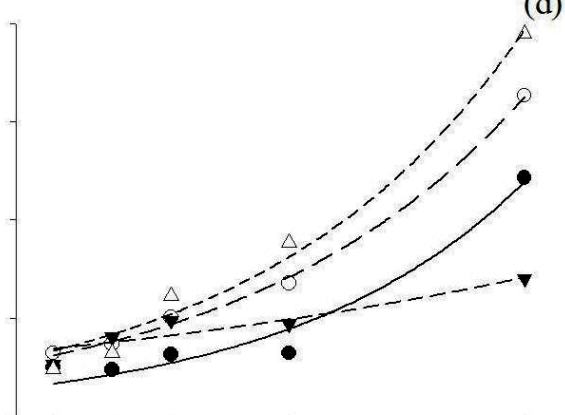

$\begin{array}{lllll}0 & 80 & 160 & 320 & 640\end{array}$

Row/A — $\hat{\mathrm{y}}=1.981 \mathrm{e}^{(0.0031 \mathrm{x})} \mathrm{R}^{2}=0.96^{* * * *}$

$\operatorname{Row} / \mathrm{B} 0---\hat{\mathrm{y}}=3.705 \mathrm{e}^{(0.0026 \mathrm{x})} \mathrm{R}^{2}=0.99 * * *$

Between row/A $\mathbf{-}---\hat{\mathrm{y}}=4.116 \mathrm{e}^{(0.0011 \mathrm{x})} \mathrm{R}^{2}=0.85^{* * *}$

Between row/B $\triangle$-.-.. $\hat{y}=4.002 e^{(0.0028 x)} R^{2}=0.97^{* * *}$

Dose $\left(\mathrm{kg} \mathrm{ha}^{-1}\right.$ of $\left.\mathrm{P}_{2} \mathrm{O}_{5}\right)$

Figure 3. Content of $\mathrm{P}$ in the soil at the harvest time, in row and between rows, by Mehlich-1 and Mehlich-3 extractors. *** significant at $0.1 \%$ by the t-test. A: soil with low content of P; B: soil with high content of $\mathrm{P}$.

the localized application showed better efficiency indices for the phosphate fertilization. These results show that minimizing the fixation by location of $\mathrm{P}$ is essential for a greater efficiency of phosphate fertilizations.

\section{CONCLUSIONS}

1. The localized application of $\mathrm{P}$ allows reaching a yield similar to that obtained at the broadcasting application and with smaller rates of applied P;

2. Phosphate associated with localized application of $\mathrm{P}$ increases the yield only in soil with a lower content of $\mathrm{P}$ and reduced agronomic and recovery efficiencies;

3. The localized application of $\mathrm{P}$ is more efficient than the broadcasting application to guarantee adequate levels of $\mathrm{P}$ near the plant roots with the application of lower rates of $\mathrm{P}$.

\section{ACKNOWLEDGMENTS}

To the Coordenação de Aperfeiçoamento de Pessoal de Nível Superior (Capes), for granting scholarships and financial support; HF Fênix (São Gotardo - MG), for the support during the conduction of the experiments; and 
Conselho Nacional de Desenvolvimento Científico e Tecnológico $(\mathrm{CNPq})$, for funding the project and providing a research productivity grant to the second author.

\section{REFERENCES}

AQUINO, L. A. et al. Produção de biomassa, teor e exportação de macronutrientes em plantas de repolho em função de doses de nitrogênio e de espaçamentos. Ciência e Agrotecnologia, v. 33, n. 5, p. 1295-1300, 2009.

ASSOCIAÇÃONACIONALDE DIFUSÃODEADUBOS (ANDA). Anuário estatístico. 2015. Available at: $<\mathrm{http}: / /$ www.anda.org.br/index.php?mpg=03.00.00\&ver=por $>$. Access on: 12 Oct. 2016.

BARBOSA, N. C. et al. Distribuição vertical do fósforo no solo em função dos modos de aplicação. Bioscience Journal, v. 31, n. 1, p. 87-95, 2015.

BÜLL, L. T. et al. Doses and forms of application of phosphorus in vernalized garlic. Scientia Agricola, v. 61, n. 5, p. 516-521, 2004.

CARNEIRO, L. F. et al. Fontes, doses e modos de aplicação de fósforo na interação fósforo-zinco em milho. Ciência e Agrotecnologia, v. 32, n. 4, p. 1133-1141, 2008.

CECÍlIO FILHO, A. B. et al. Cabbage growth and production in relation to plant density and nitrogen. Agrociência, v. 45, n. 5, p. 573-582, 2011.

CECÍlIO FILHO, A. B.; SILVA, G. S.; CORTEZ, J. W. M. Phosphorus fertilization of 'Fuyutoyo' cabbages in phosphorus-rich Eutrustox soil. Chilean Journal of Agricultural Research, v. 73, n. 3, p. 288-292, 2013.

CHIEN, S. H. et al. Agronomic and environmental aspects of phosphate fertilizers varying in source and solubility: an update review. Nutrient Cycling in Agroecosystems, v. 89, n. 2, p. 229-255, 2010.

CORREA, C. V.; CARDOSO, A. I. I.; CLAUDIO, M. D. T. R. Produção de repolho em função de doses e fontes de potássio em cobertura. Semina: Ciências Agrárias, v. 34, n. 5 , p. 2129-2138, 2013.

COSTA, J. P. V. et al. Fluxo difusivo de fósforo em função de doses e da umidade do solo. Revista Brasileira de Engenharia Agrícola e Ambiental, v. 10, n. 4, p. 828-835, 2006.

DECHASSA, N.; SCHENK, M. K. Exudation of organic anions by roots of cabbage, carrot, and potato as influenced by environmental factors and plant age. Journal of Plant Nutrition and Soil Science, v. 167, n. 5, p. 623-629, 2004.

DEENIK, J. et al. Phosphorus fertilizer management for head cabbage. Soil and Crop Management, v. 16, n. 1, p. 1-6, 2006.
FAGERIA, N. K. The use of nutrients in crop plants. Boca Raton: CRC Press, 2009.

FONTES, P. C. R. Repolho. In: RIBEIRO, A. C.; GUIMARÃES, P. T. G.; ALVAREZ V., V. H. (Eds.). Recomendações para o uso de corretivos e fertilizantes em Minas Gerais: $5^{\text {a }}$ aproximação. Viçosa: Comissão de Fertilidade do Solo do Estado de Minas Gerais, 1999. p. 203-204.

FRANZINI, V. I. et al. Eficiência de fosfato natural reativo aplicado em misturas com superfosfato triplo em milho e soja. Pesquisa Agropecuária Brasileira, v. 44, n. 9, p. 1092-1099, 2009.

GONÇALVES, F. A. R. Modos de aplicação de fósforo na cultura da cenoura e adsorção iônica em biochar de batata. 2018. 50 f. Dissertação (Mestrado em Produção Vegetal) - Instituto de Ciências Agrárias, Universidade Federal de Viçosa, Rio Paranaíba, 2018.

MALAVOLTA, E.; VITTI, G. C.; OLIVEIRA, S. A. Avaliação do estado nutricional das plantas: princípios e aplicações. Piracicaba: Potafos, 1997.

MEHLICH, A. Mehlich 3 soil test extractant: a modification of Mehlich 2 extractant. Communications in Soil Science \& Plant Analysis, v. 15, n. 12, p. 1409-1416, 1984.

MIYAZAWA, K. et al. Combining pre-transplanting phosphorus application and green manure incorporation: a trial for reducing fertilizer input. Soil Science and Plant Nutrition, v. 57, n. 1, p. 128-137, 2011.

MOREIRA, M. A. et al. Crescimento e produção de repolho em função de doses de nitrogênio. Horticultura Brasileira, v. 29, n. 1, p. 117-121, 2011.

NOVAIS, R. F.; SMYTH, T. J. Aplicação localizada do fertilizante fosfatado. In: NOVAIS, R. F.; SMYTH, T. J. Fósforo em solo e planta em condições tropicais. Viçosa: Ed. UFV, 1999. p. 271-288.

NOVAIS, R. F.; SMYTH, T. J.; NUNES, F. N. Fósforo. In: NOVAIS, R. F. et al. (Eds.). Fertilidade do solo. Viçosa: Sociedade Brasileira de Ciência do Solo, 2007. p. 471-550.

NUNES, R. S. et al. Distribuição de fósforo no solo em razão do sistema de cultivo e manejo da adubação fosfatada. Revista Brasileira de Ciência do Solo, v. 35, n. 3, p. 877-888, 2011.

OLIVEIRA JÚNIOR, A.; PROCHNOW, L. I.; KLEPKER, D. Eficiência agronômica de fosfato natural reativo na cultura da soja. Pesquisa Agropecuária Brasileira, v. 43, n. 5, p. 623-631, 2008.

PEEL, M. C.; FINLAYSON, B. L.; MCMAHON, T. A. Updated world map of the Köppen-Geiger climate classification. Hydrology and Earth System Sciences, v. 4, n. 2, p. 1633-1644, 2007. 
RAIJ, B. V. Fertilidade do solo e manejo de nutrientes. Piracicaba: International Plant Nutrition Institute, 2011.

RESENDE, A. V. et al. Fontes e modos de aplicação de fósforo para o milho em solo cultivado da região do Cerrado. Revista Brasileira de Ciência do Solo, v. 30, n. 3, p. 453-466, 2006.

SANTOS, J. Z. L. et al. Frações de fósforo em solo adubado com fosfatos em diferentes modos de aplicação e cultivado com milho. Revista Brasileira de Ciência do Solo, v. 32, n. 2, p. 705-714, 2008.

SHARANGI, A. B.; SAHU, P. K. Effect of placement and dose of phosphatic fertilizers on onion. Journal of Plant Nutrition, v. 32, n. 11, p. 1901-1913, 2009.
SOUSA, D. M. G. et al. Fósforo. In: PROCHNOW, L. I.; CASARIN, V.; STIPP, S. R. (Eds.). Boas práticas para uso eficiente de fertilizantes: nutrientes. Piracicaba: International Plant Nutrition Institute, 2010. p. 67-132.

TEDESCO, M. J. et al. Análise de solo, plantas e outros materiais. Porto Alegre: Ed. UFRGS, 1995.

TRANI, P. E. et al. Brócolis, couve-flor e repolho. In: RAIJ, B. V. et al. (Eds.). Recomendações de adubação e calagem para o Estado de São Paulo. Campinas: IAC, 1997. (Boletim técnico, 100).

TRANI, P. E.; RAIJ, B. V. Hortaliças. In: RAIJ, B. V. et al. (Eds.). Recomendações de adubação e calagem para o Estado de São Paulo. Campinas: IAC, 1997. p. 157-164. 